\title{
Preliminary Report on the Effect of Pre-Boring on the Mobilized Friction Capacity of Pile Foundation Hydraulically Jacked into Expansive Soil
}

\author{
Budi, G.S. ${ }^{1}$
}

\begin{abstract}
Pre-drilling was performed to reduce lateral earth pressure generated by pile foundation hydraulically jacked into expansive soil. Nineteen prestressed-precast spun concrete piles with diameter of $800 \mathrm{~mm}$ were penetrated into expansive soil up the depth of $40 \mathrm{~m}$. Predrilling with diameter of $700 \mathrm{~mm}$ was carried out up to the depth of $12.5 \mathrm{~m}$. Penetration loads required to install the piles, which were displayed on the built-in pressure panel, were recorded every $1 \mathrm{~m}$ interval. The load that merely consists of shaft friction is then used to find out the mobilized skin friction between pile shaft and its surrounding soils. The calculated mobilized skin friction is correlated to the value of Standard Penetration Test (NSPT) and compared to that computed by Decourt formula. The result shows that skin friction calculated using Decourt formula relatively conservative compared to those determined from the records of field penetration. The upper bound of mobilized skin friction can be defined by modifying Decourt formula.
\end{abstract}

Keywords: Expansive soils, jack-in piles, shaft friction.

\section{Introduction}

Installation of pile foundations using displacement methods such as driven pile and jacked-in pile might affect its neighboring structures due to lateral earth pressure generated by movement of surrounding soils. The effect of piling activity to the surrounding soil diminishes beyond 7 times of pile diameter from the pile [1]. In other words, the soil and structures in the range of 7 times diameter of the pile will be affected by intallation of displacement pile foundations.

Pre-boring is a common method to reduce the undesirable effect due to lateral earth movement (pressure) generated by installation of driven piles or jacked-in pile foundation. The diameter of pre-drilling has to be smaller than that of the pile foundation so that the skin friction between soil and pile shaft remains unchanged. Broms [2] stated that for friction piles in clays, the outside diameter of the pre-drilling must be four centimeter less than that of the pile so that the friction resistance between soil and pile shaft unaffected by pre-drilling. Queensland Department of Transport and Main Roads [3] stated that in order to maintain the friction capacity of pile foundations, the difference between pile and pre-drilling diameter must be larger than five centimeter.

${ }^{1}$ Department of Civil Engineering, Petra Christian University, Jl Siwalankerto 121-131, Surabaya 60236, INDONESIA.

E-mail: gogot@petra.ac.id

Note: Discussion is expected before June, $1^{\text {st }} 2015$, and will be published in the "Civil Engineering Dimension" volume 17, number 2, September 2015.

Received 10 February 2015; revised 11 March 2015; accepted 16 March 2015.

\section{Case Study}

Pre-drilling method is being carried out to install 800 $\mathrm{mm}$ diameter pre-stressed precast concrete spun pile into expansive soil layer in West Surabaya, Indonesia. The expansive potential of soil layers is presented in Table 1. A Continuous Flight Auger (CFA) with diameter of $700 \mathrm{~mm}$ was used to pre-drill soil column up to the depth of $12.5 \mathrm{~m}$. Out of about 550 piles scheduled to be installed, three piles with $40 \mathrm{~m}$ length were hydraulically jacked into the $40 \mathrm{~m}$ depth, eight $26 \mathrm{~m}$ piles were installed up to the depth of $40 \mathrm{~m}$ using follower with the same diameter, and eight 36 $\mathrm{m}$ piles were jacked into $36 \mathrm{~m}$ deep.

The hydraulic jack-in machine (type JVY 700) that is used to install the piles was manufactured by CHTC Jove Heavy Industry Co, LTD - China. The machine exhibits maximum penetration capacity of 700 ton, maximum rate of penetration (pile pressing speed) of $1.48 \mathrm{~m}$ per minute, and penetration stroke of $1.80 \mathrm{~m}$ [4]. The mobilized pressure to penetrate the piles was monitored and recorded each and every $1 \mathrm{~m}$ through built-in pressure gauge indicator that is displayed in the operational compartment of the machine.

Table 1. Heaving Potential

\begin{tabular}{ccc}
\hline Depth, $\mathrm{m}$ & Heave, $\%$ & Bor \\
\hline $11.5 \mathrm{~m}-12.0 \mathrm{~m}$ & 1.3 & $\mathrm{~B} 1$ \\
$15.0 \mathrm{~m}-16.0 \mathrm{~m}$ & 3.3 & $\mathrm{~B} 1$ \\
$21.5 \mathrm{~m}-22.0 \mathrm{~m}$ & 3.3 & $\mathrm{~B} 1$ \\
$13.0 \mathrm{~m}-13.5 \mathrm{~m}$ & 2.3 & $\mathrm{~B} 2$ \\
$17.0 \mathrm{~m}-17.5 \mathrm{~m}$ & 1.8 & $\mathrm{~B} 2$ \\
$17.5 \mathrm{~m}-18.0 \mathrm{~m}$ & 3.5 & $\mathrm{~B} 3$ \\
$23.5 \mathrm{~m}-24.0 \mathrm{~m}$ & 3.6 & $\mathrm{~B} 3$ \\
$13.0 \mathrm{~m}-13.7 \mathrm{~m}$ & 1.2 & $\mathrm{~B} 4$ \\
$17.5 \mathrm{~m}-18.0 \mathrm{~m}$ & 2.9 & $\mathrm{~B} 4$ \\
$21.5 \mathrm{~m}-22.0 \mathrm{~m}$ & 3.8 & $\mathrm{~B} 5$ \\
\hline
\end{tabular}




\section{Soil Data}

Soil investigation [5] that consists of five borings was performed up to the depth of $60 \mathrm{~m}$. It was reported that the undrained shear strength of soil increases with depth (Figure 1), with average undrained shear strength of $4 \mathrm{ton} / \mathrm{m}^{2}$. The value of Standard Penetration Test $\left(\mathrm{N}_{\mathrm{SPT}}\right)$ that was conducted at every $2 \mathrm{~m}$ interval is presented in Figure 2. In general, the NspT increases linearly with depth. Figure 2 also shows that soil layers in the location of the project are relatively homogenous. For the purpose of clarity, the Uncorrected Standard Penetration Test (NSPT) up the depth of $14 \mathrm{~m}$ is presented in Figure 3. The mean Standard Penetration Test of $14 \mathrm{~m}$ thick of upper layer soil can be correlated linearly with depth, as shown in Figure 3.

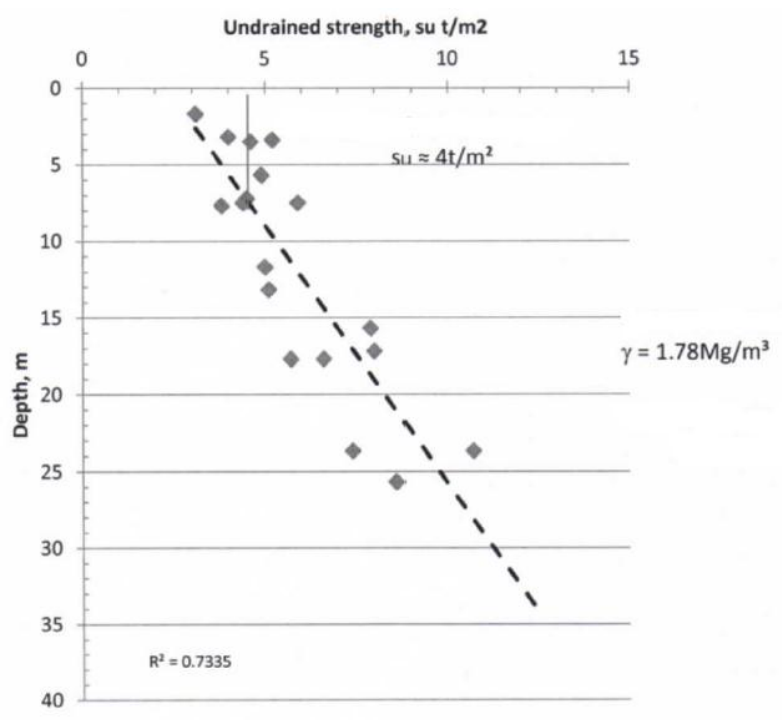

Figure 1. Undrained Shear Strength (Su) of Soil Layers
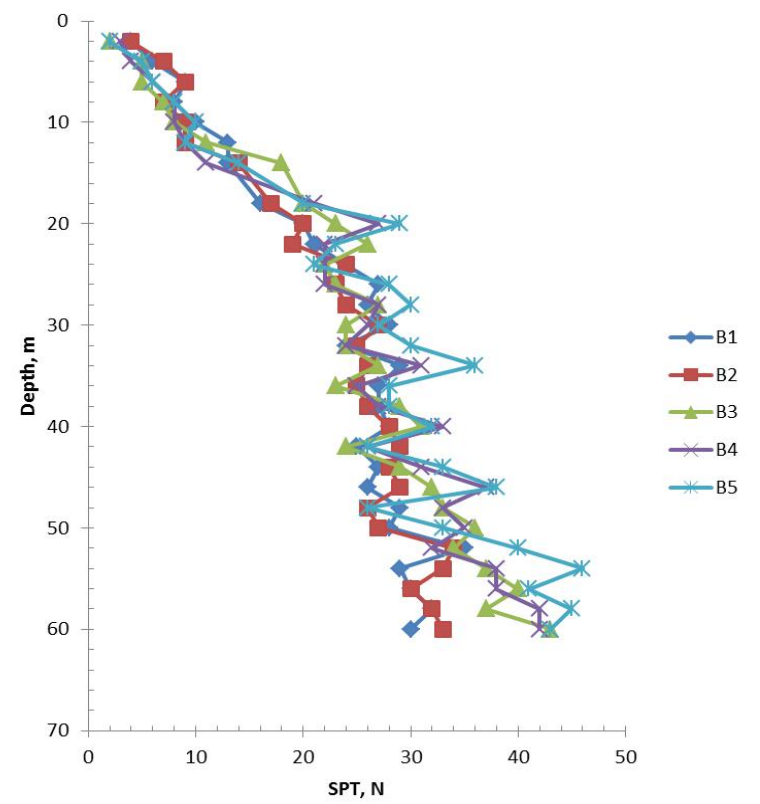

Figure 2. Uncorrected Standard Penetration Test (NSPT)

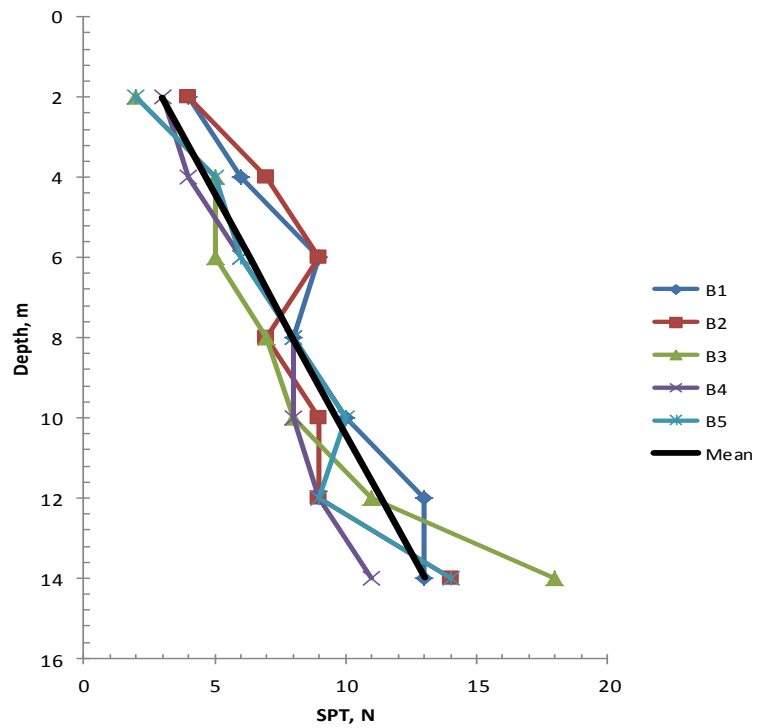

Figure 3. Average Uncorrected Standard Penetration Test (NSPT)

\section{Penetration Load Data}

Figure 4 shows the loads applied to install the piles. Maximum load required to penetrate 19 piles ranging from 540 ton to 640 ton. While Figure 5 shows the penetration load required to install the first $12 \mathrm{~m}$ of the piles, where the bearing capacity of piles comprises of merely on shaft friction.

\section{Mobilized Shaft Friction $(f s)$}

Mobilized unit skin friction of piles $(f s)$ is determined by averaging load of penetration at every $2 \mathrm{~m}$ interval divided by surface area of the pile at the same interval. The first $3 \mathrm{~m}$ deep of the penetration data are omitted since the soil at this layer consisted of non-expansive fill material.

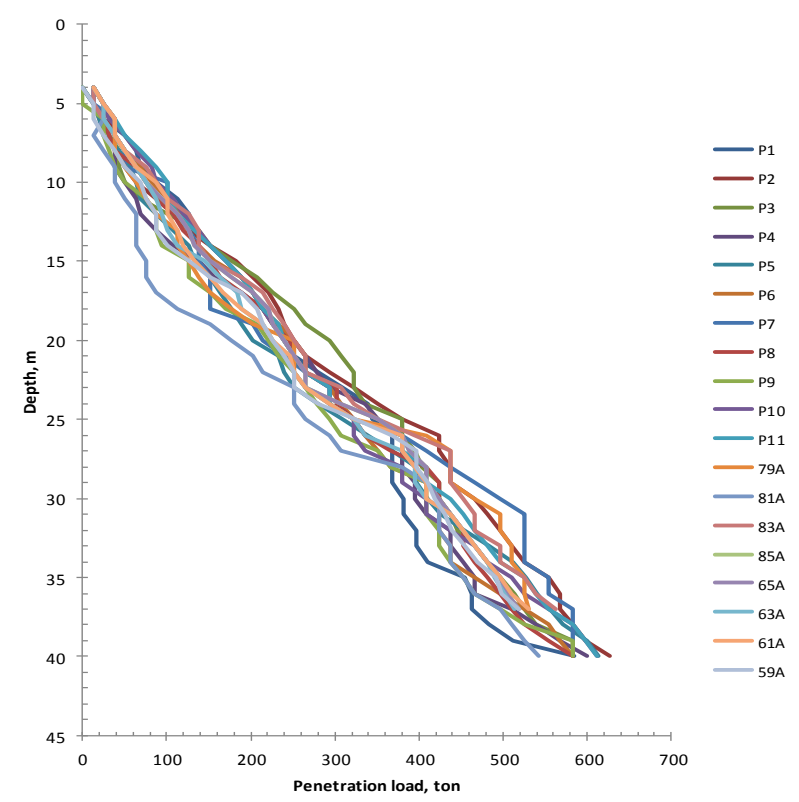

Figure 4. Load of Penetration with Depth 


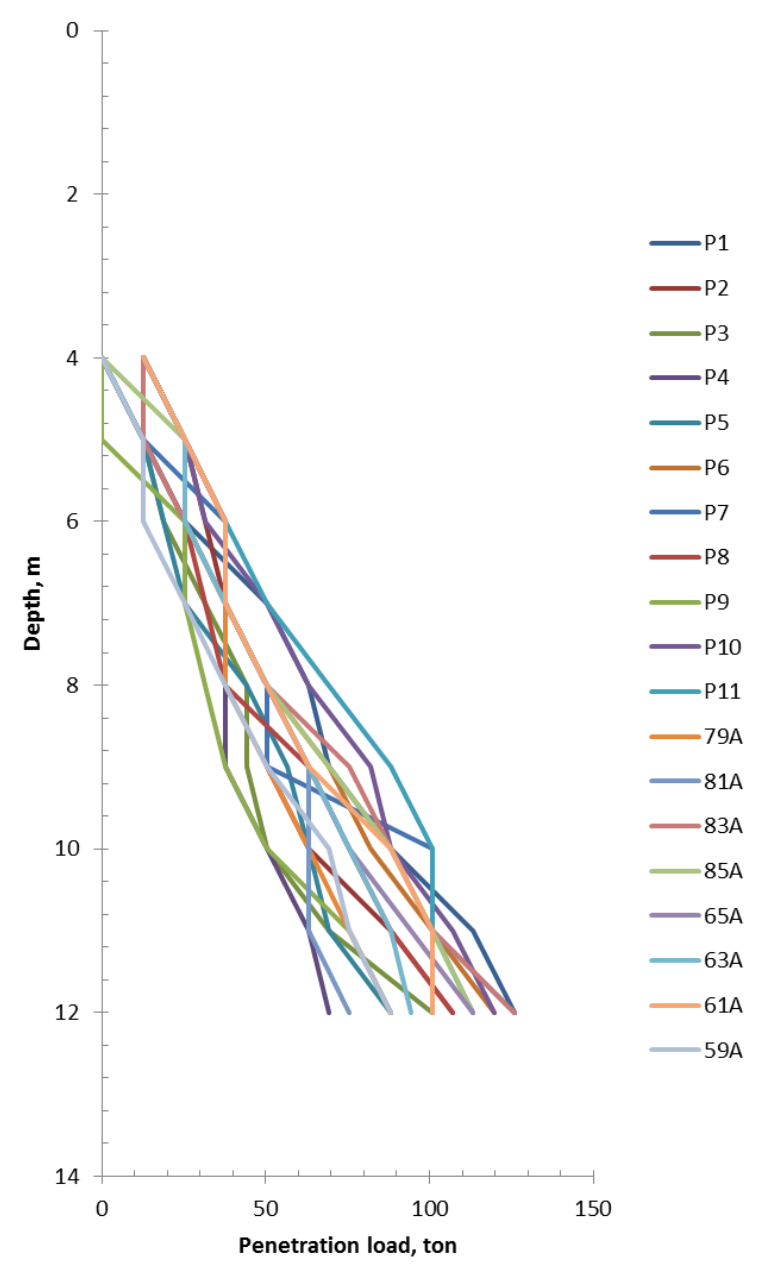

Figure 5. Load of Penetration Required to Install the First $12.5 \mathrm{~m}$ of the Piles

Figure 6 shows the mobilized unit shaft friction of the piles up $12 \mathrm{~m}$ deep. It shows that, in general, the mobilized unit shaft friction of the piles increases with depth. However, the variation of calculated mobilized unit shaft friction is quite large. Comparing the calculated unit shaft frictions to those proposed by Decourt [6] and Schmertmann [7], which are expressed in Equation 1 and Equation 2 respectively, the unit shaft friction stated by both Decourt and Schmertmann are within the calculated mobilized shaft friction, as shown in Figure 6.

The mean value of Standard Penetration Test of five borings up to $14 \mathrm{~m}$ deep, which is expressed in Equation 3, is used to calculate the unit shaft friction proposed by Decourt and Schmertmann formulas;

$f s=\frac{N_{S P T}}{3}+1\left[\mathrm{ton} / \mathrm{m}^{2}\right]$

$f s=0.5 N_{S P T}\left[\mathrm{ton} / \mathrm{m}^{2}\right]$

$N_{S P T}=1.1932(\mathrm{z})-1.58$, where $\mathrm{z}$ represents the depth

Bromham and Styles [8] mentioned that Meyerhof formula for sands [9], which is presented in Equation
4, could also be used to predict shaft resistance for stiff clays;

$f s=\frac{N_{S P T}}{5}\left[\mathrm{ton} / \mathrm{m}^{2}\right]$

However, the skin friction determined using Meyerhof formula (Equation 4) is more conservative compared to that proposed by Schmertmann (Equation 2)

Figure 6 also shows that Decourt formula considered as lower limit of mobilized shaft friction. Trial and error on Decourt formula was exercised to determine the upper bound of calculated unit skin friction. The upper bound of the calculated mobilized unit skin friction could be expressed as;

$f s=\frac{N_{S P T}}{3}+4$ ton $/ \mathrm{m}^{2}$

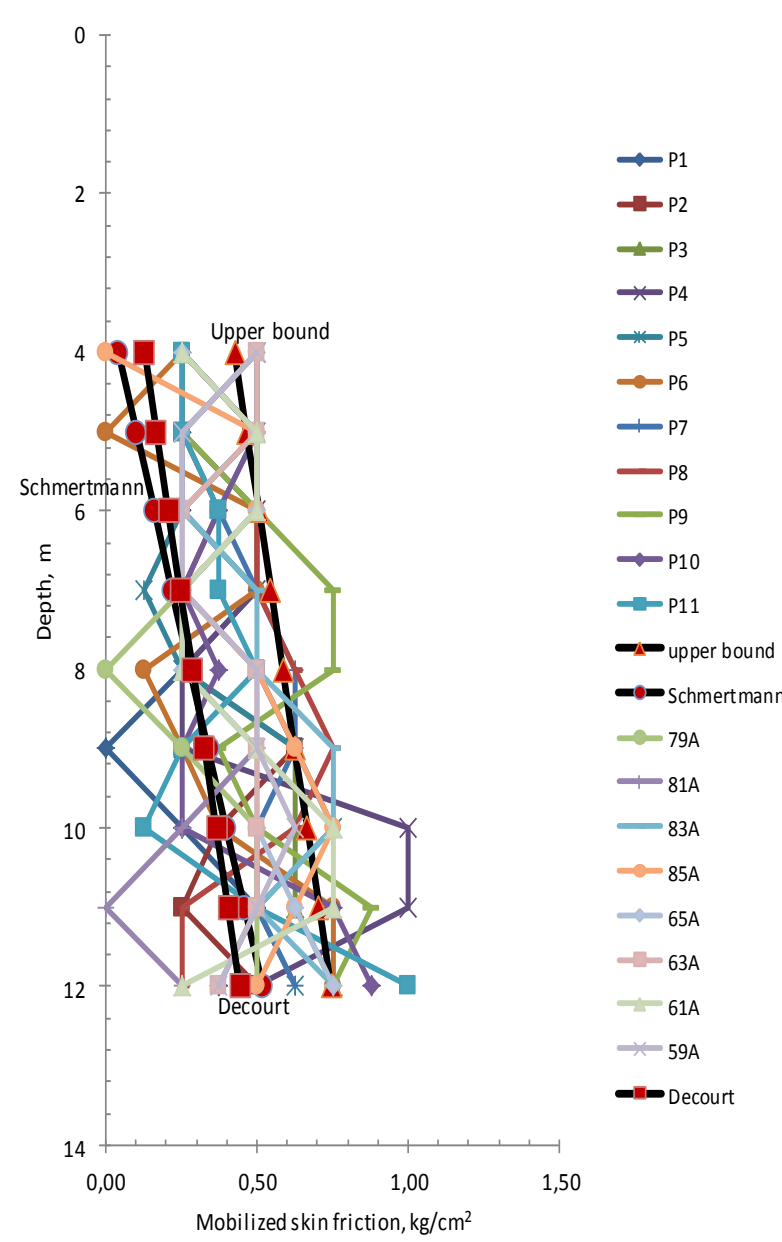

Figure 6. Mobilized Unit Skin Friction

\section{Conclusion}

Based on limited number of data, the preliminary research on shaft friction shows that the mobilized skin friction of concrete pile foundation hydraulically jacked into expansive soil can be determined conservatively using Decourt formula. The upper bound of mobilized skin friction can be calculated using modified Decourt formula, as shown in (Equation 5). 


\section{References}

1. Poulos, H.G., Effect of Pile Driving on Adjacent Piles in Clay, Canadian Geotechnical Journal, 31, 1994, pp. 856-867.

2. Broms, B.B., Precast Piling Practice, Thomas Telford LTD, London, 1981.

3. Transport and Main Roads Specifications, MRTS65, Technical Specification, State of Queensland Department of Transport and Main Roads, April, 2011.

4. Operation's Manual JVY700, CHTC Jove Heavy Industry Co., Ltd-China.

5. Data Persada, Soil Investigation Report, November, 2013.
6. Decourt, L., Prediction of the Bearing Capacity of Piles Based Exclusively on Values of the SPT, Proceeding of the Second European Symposium on Penetration Testing, Amsterdam, 24-27 May, 1982, pp. 29-34.

7. Schmertmann, J.H., Static Cone Penetrometers for Soil Exploration, Civil Engineering, 37(6), 1967, pp. 71-73.

8. Bromham, S.B. and Styles, J.R., An Analysis of Pile Loading Tests in Stiff Clay, Proceeding of the First Australian- New Zealand Conference on Geomechanics, Melbourne, 1, 1971, pp. 246-253.

9. Meyerhof, G.G., Bearing Capacity and Settlement of Pile Foundations, The Eleventh Terzaghi Lecture, November 5, 1975, Journal of Geotechnical Engineering, ASCE, 102(GT-3), 1976, pp. 195-228. 